\title{
Archaeological Investigations at the Wade (GC-38) and Estes (GC-49) Sites in the Sabine River Basin, Gregg County, Texas
}

Timothy K. Perttula

Heritage Research Center, Stephen F. Austin State University

Robert Z. Selden Jr.

Heritage Research Center, Stephen F. Austin State University

Bo Nelson

Heritage Research Center, Stephen F. Austin State University

Follow this and additional works at: https://scholarworks.sfasu.edu/ita

Part of the American Material Culture Commons, Archaeological Anthropology Commons, Environmental Studies Commons, Other American Studies Commons, Other Arts and Humanities Commons, Other History of Art, Architecture, and Archaeology Commons, and the United States History Commons

Tell us how this article helped you.

This Article is brought to you for free and open access by the Center for Regional Heritage Research at SFA ScholarWorks. It has been accepted for inclusion in Index of Texas Archaeology: Open Access Gray Literature from the Lone Star State by an authorized editor of SFA ScholarWorks. For more information, please contact cdsscholarworks@sfasu.edu. 
Archaeological Investigations at the Wade (GC-38) and Estes (GC-49) Sites in the Sabine River Basin, Gregg County, Texas

\section{Creative Commons License}

(c) (1) (8)

This work is licensed under a Creative Commons Attribution-NonCommercial 4.0 International License 


\title{
Archaeological Investigations at the Wade (GC-38) and Estes (GC-49) Sites in the Sabine River Basin, Gregg County, Texas
}

\author{
Timothy K. Perttula, Robert Z. Selden, Jr., and Bo Nelson
}

\section{INTRODUCTION}

Buddy C. Jones conducted extensive archaeological investigations in the 1950s and 1960s at many sites in the mid-Sabine River basin of East Texas, especially on Caddo sites of various ages in Gregg, Harrison, and Rusk counties. However, that work has not illuminated our understanding of the archaeology of the Caddo Indian peoples that lived along this stretch of the Sabine River as much as it could have, primarily because little of the work completed by Joncs was ever published (see Jones 1957, 1968), or the results and findings shared with professional and avocational archaeological colleagues working in the region. The Caddo archaeology of the Gregg County stretch of the Sabine River, in particular, is poorly known by comparison with the archacological record in the upper Sabine River (cf. Perttula 1995) or to the archaeological studies recently completed downstream in Harrison County at sites such as Pine Tree Mound (41HS15) (sec Fields and Gadus 2012).

To begin to develop a better appreciation of the Caddo archaeology in the mid-Sabine River basin, we have madc a concerted effort to analyze and document collections obtained by Jones from Caddo sites in Gregg County and the surrounding region (see Perttula 2011,2012, 2013; Perttula and Nelson 2013; see also other articles in this volume of the Journal of Northeast Texas Archaeology). In this article, we discuss the archaeological findings from the Wade and Estes sites discovered and investigated by Jones in the late 1950s and early 1960s.

The sites are near each other in the southeastern part of Gregg County (Figure 1). The Wade site is on a landform near the confluence of Peatown Creek and Dutchman Creek, northern-flowing tributaries to the Sabine River. The Estes site is on a large alluvial terrace on the north side of the Sabine River, across from the confluence of Dutchman Creek and the Sabine River This article focuses particularly on the excavations of portions of an ancestral Caddo house structure at the Wade site and the analysis of the substantial decorated sherd assemblages at both the Wade and Estes sites.

\section{THE WADE SITE (GC-38)}

Buddy C. Jones found the Wade site in 1955, and he apparently collected ceramic and lithic artifacts from the surface of the site for several years. In 1959-1961, he completed limited excavations at the site, this work consisting of several narrow trenches and four $5 \times 5 \mathrm{ft}$. units (Squares 1-4) in a small block off one of the trenches. Evidence of pits, post holes, and concentrations of daub in several areas of his work indicate that Jones encountered the remains of at least one ancestral Caddo house structure in the small block and trenches. The collections to be discussed below are from both the surface collections and hand excavations, but they are considered as one assemblage for analytical purposes.

\section{Excavations}

After noting that ceramic sherds were abundant on the surface of the Wade site in 1958, Jones excavated three narrow northwest-southeast and northeast-southwest oriented trenches across one part of the site (Figure 


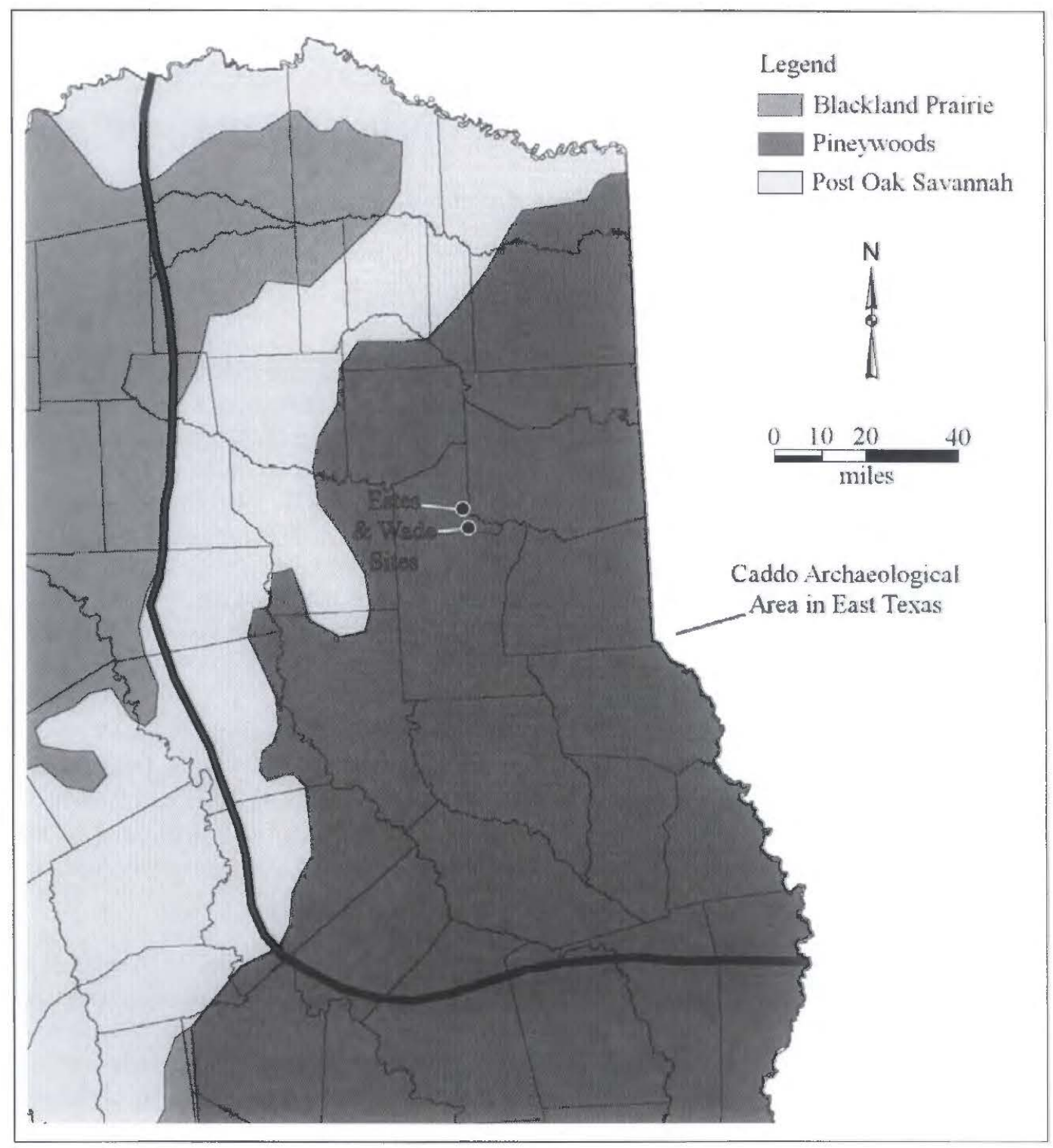

Figure 1. The location of the Wade and Estes sites in East Texas. Figure prepared by Lance Trask.

2). These trenches were an unspecified width (likely 2 feet in width, based on his use of similar trenches in the 1957 excavations at the Henry Spencer site [4IUR315], see Perttula et al. [2012:Figure 3|) and were probably dug in $10 \mathrm{ft}$. sections. Trench A was $75 \mathrm{ft}$. in length, Trench B was $55 \mathrm{ft}$. in length, and Trench C was $70 \mathrm{ft}$. in length, for a total of $200 \mathrm{ft}$. of hand-excavated trenches.

Cultural features, including pits and post holes, were present in the trenches (see Figure 2), and Jones continued his excavations in 1961 at the Wade site by excavating four $5 \times 5 \mathrm{ft}$. squares (Units $1-4,100 \mathrm{ft}^{2}{ }^{2}$ ) in the area of what he called an ash pit, possibly a hearth, found in Trench $\mathrm{C}$; these units were excavated in 3 inch levels. These excavations first encountered a plow zone $(0-15 \mathrm{~cm})$, followed by a dark midden deposit from $15-30 \mathrm{~cm}$ bs; this deposit contained animal bone, mussel shells, and pottery sherds (Figure 3). A pit with about $5 \mathrm{~cm}$ of ash was encountered in Unit 2 at $30 \mathrm{~cm}$ bs (found in it were a pitted stone, pottery sherds, deer bone, and a single Yarbrough point). A number of post holes $(\mathrm{n}=11)$ and possible post holes $(\mathrm{n}=6)$ were defined at about $40 \mathrm{~cm}$ bs in the units (particularly in Units 3 and 4), in the middle part of the sandy E-horizon, extending to ca. $66 \mathrm{~cm}$ bs in the B-horizon clay subsoil. The post holes ranged from 15 - 


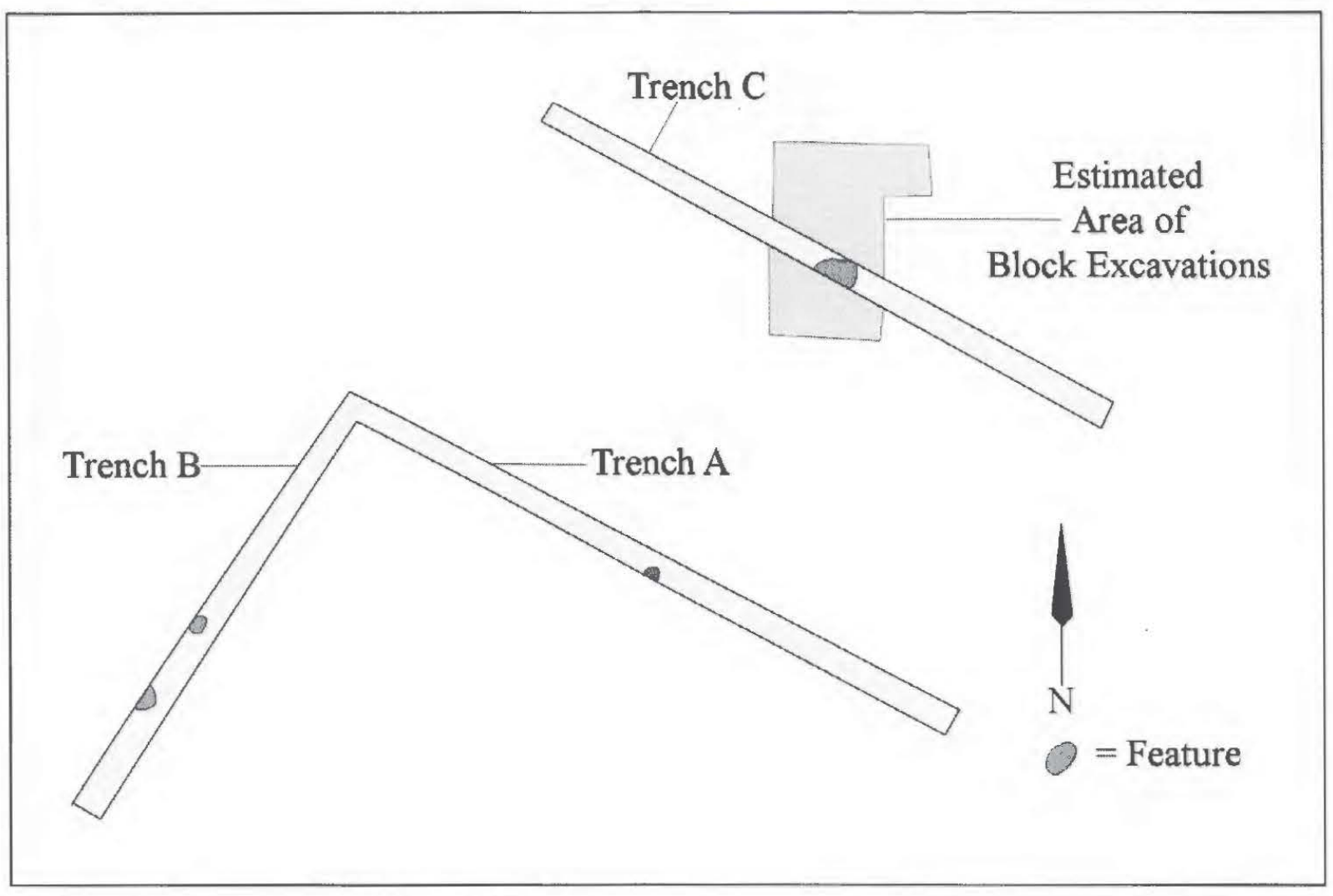

Figure 2. Trench excavations at the Wade site.

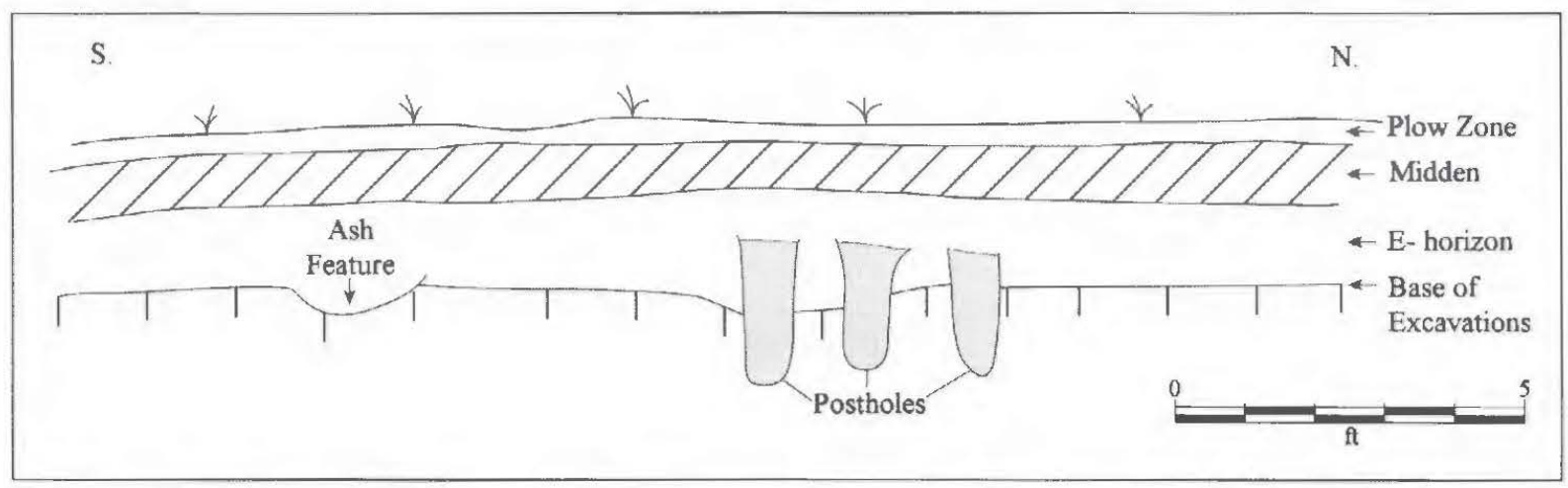

Figure 3. Profile of the excavations at the Wade site.

$20 \mathrm{~cm}$ in diameter, and likely mark wall posts to a Caddo structure; no clear wall pattern can be discerned in the small excavated area, but there may have been more than one possible rectangular structure built at this location given the proximity of two roughly north-south lines of posts in Units 3 and 4 (Figure 4); these posts may also mark a rebuilt wall. In these same units was a ca. $1.5 \times 1 \mathrm{~m}$ concentration of daub that was encountered immediately below the midden deposits, from ca. $30-40 \mathrm{~cm}$ bs; several post holes lie beneath the daub. The daub deposit elearly indicates that the structure or structures on this part of the Wade site had been clay, grass, and thatch-covered, and at some point had been burned down, preserving the daub from the structure walls. 


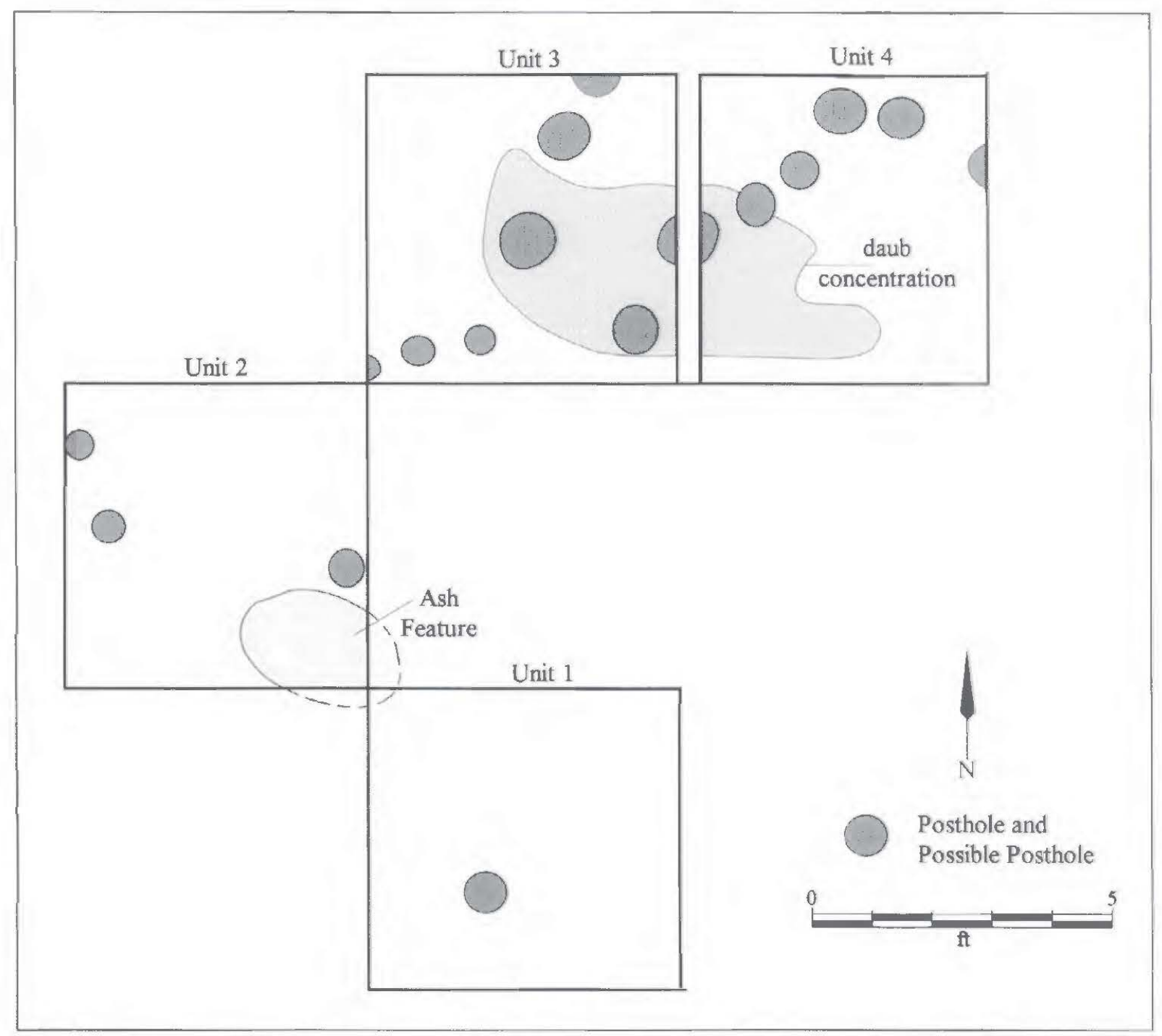

Figure 4. Plan map of post holes/possible post holes, daub concentration, and ash feature in the excavations at the Wade site.

\section{Ceramic Assemblage}

The ceramic vessel sherd assemblage $(n=1472)$ from Jones' investigations at the Wade site consists of 678 plain rim, body, and base sherds and 794 decorated sherds from utility ware $(n=688)$ and fine ware $(n=106)$ vessels. The plain to decorated sherd ratio $(P / D R)$ is 0.86 . One of the plain rims has a Redwine mode lip treatment (see Walters 2010).

More than $85 \%$ of the sherds are from grog-tempered vessels, with $14.7 \%$ of the sherds from vessels tempered with burned bone (Table 2). The proportions of bone temper use in the three wares at the Wade site is generally similar, with the highest use of bone temper in utility ware jars and the lowest bone temper use in the fine wares.

Plain ware vessels are a significant component of the Wade site ceramic assemblage, given that $35 \%$ of the rims from the site are from plain ware vessels. Another $16 \%$ of the rims are from fine wares, and the remaining $49 \%$ are from utility wares (see Table 1). 
Table 1. Ceramic sherd assemblage from the Wade site.

\begin{tabular}{|c|c|c|c|c|c|}
\hline Ware & $\operatorname{Rim}$ & Body & Base & $\mathrm{N}$ & $\%$ \\
\hline Plain ware & 51 & 543 & 84 & 678 & 46.0 \\
\hline \multicolumn{6}{|l|}{ Utility ware } \\
\hline Appliqued & - & 5 & - & 5 & 0.3 \\
\hline Brushed & 11 & 264 & - & 275 & 16.9 \\
\hline Brushed-Appliqued & - & 12 & - & 12 & 0.8 \\
\hline Brushed-Incised & 5 & 73 & - & 78 & 5.3 \\
\hline Brushed-Incised-Appliqued & - & 1 & - & 1 & 0.1 \\
\hline Brushed-Incised-Punctated & - & 2 & - & 2 & 0.1 \\
\hline Brushed-Punctated & 8 & 18 & - & 26 & 1.8 \\
\hline Incised & 14 & 89 & - & 103 & 7.0 \\
\hline Incised-Appliqued & - & 1 & - & 1 & 0.1 \\
\hline Incised-Punctated & 19 & 35 & - & 54 & 3.7 \\
\hline Pinched & - & 2 & - & 2 & 0.1 \\
\hline Pinched-Punctated & - & 1 & - & 1 & 0.1 \\
\hline Punctated & 14 & 114 & - & 128 & 8.7 \\
\hline \multicolumn{6}{|l|}{ Fine ware } \\
\hline Engraved & 23 & 80 & - & 103 & 7.0 \\
\hline Red-slipped & 1 & 2 & - & 3 & 0.2 \\
\hline Totals & 146 & 1242 & 84 & 1472 & 100.0 \\
\hline
\end{tabular}

Table 2. Use of bone temper in the ceramic sherds from the Wade site.

\begin{tabular}{lcc}
\hline Ware & No. of sherds & \% bone-temper \\
\hline Plain ware & 678 & 12.0 \\
Utility ware & 688 & 17.9 \\
Fine ware & 106 & 10.4 \\
\hline Totals & 1472 & 14.7 \\
\hline
\end{tabular}

Among the many utility ware sherds (comprising $87 \%$ of the decorated sherds from the site), the vessels are most commonly decorated with brushed, brushed-incised, incised, incised-punctated, and punctated decorative elements on the rim and/or the vessel body (Figure 5c-i)). Approximately 13\% of the decorated sherds are from fine ware vessels decorated with engraved lines (Figure $5 a-b, j$ ) or with red slipping on both vessel surfaces (see Table 1). 


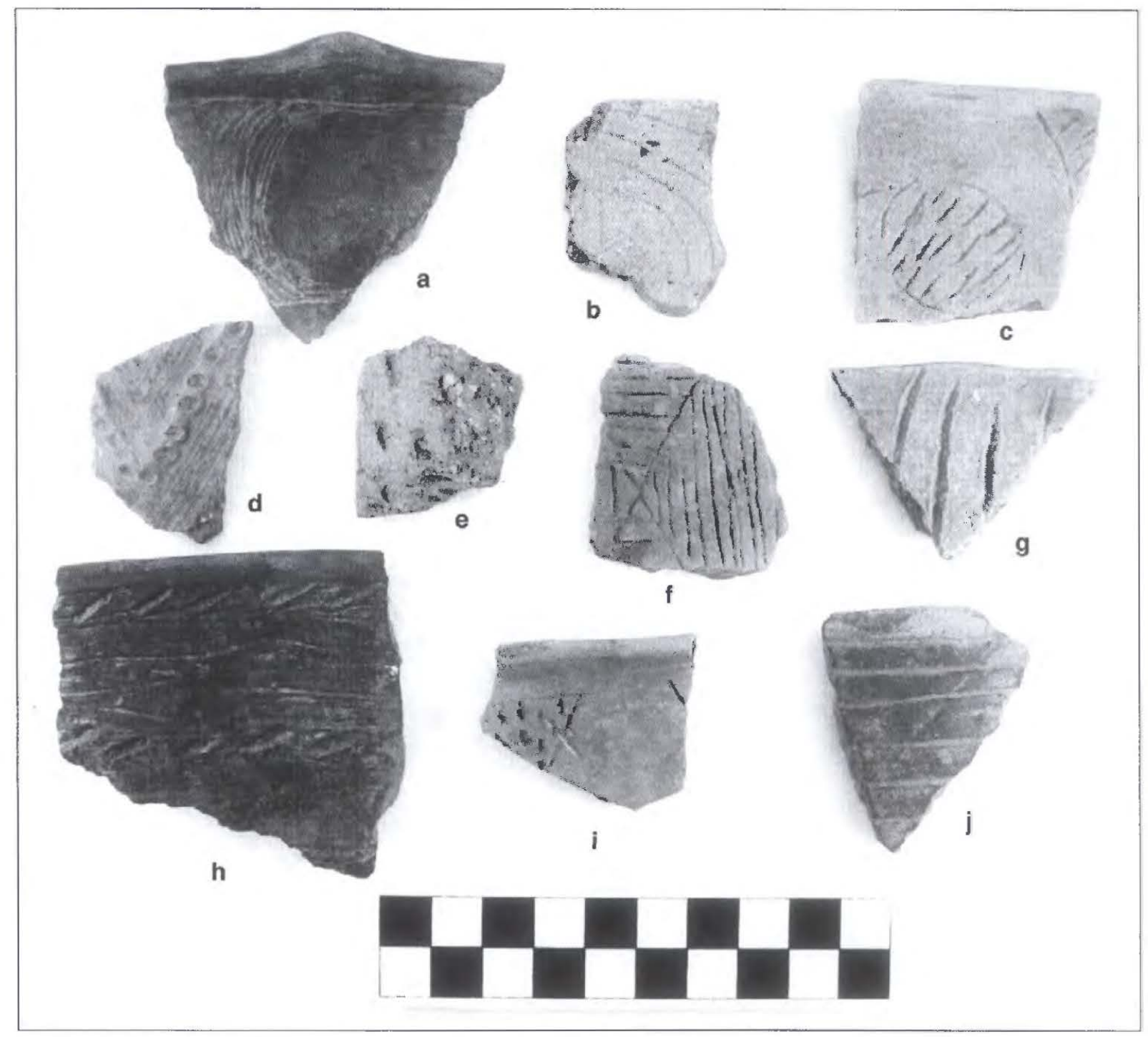

Figure 5. Examples of decorated rim and body sherds from the Wade site: a-b, j, engraved rim sherds; $c$, incised-punctated; $d$, brushed-appliqued; $\mathrm{e}$, punctated; $\mathrm{f}$-g, incised; $\mathrm{h}$, brushed-punctated; $\mathrm{i}$, incised-punctated.

The decorative elements on the utility ware rims from the Wade site feature rows of tool punctates, brushing marks in various directions as well as brushing marks and incised lines, diagonal incised lines (see Figure $5 \mathrm{~g}$ ), and brushing decorations on the rim in combination with one or more rows of tool punctations pushed through the brushing (Table 3). Rims with brushing comprise $15.5 \%$ of the utility ware rim sample in the assemblage; $7.0 \%$ of the rims have brushed-incised decorations; $11.2 \%$ have brushed-punctated decorations (Figure 6c, f; see also Figure 5h); incised rims and punctated rims both account for 19.7\% of the utility ware rims; and $26.7 \%$ of the utility ware rims have incised-punctated decorative elements (Figure $6 \mathrm{~g}, \mathrm{i}, 1$; see also Figure $5 \mathrm{c}, \mathrm{i})$.

One incised body sherd has bisected rectangle and triangle elements filled with straight lines pitched in opposite directions (see Figures $5 f$ and $6 \mathrm{k}$ ). Another incised sherd is from a Pease Brushed-Incised vessel with panels defined by sets of vertical incised lines, and the panels then filled with diagonal incised lines pitched in opposite directions (see Suhm and Jelks 1962:Plate 60k).

The incised-punctated rims from the Wade site are particularly interesting because they include nine rims from Washington Square Paneled vessels (see Figure 6a-b and Table 3). These rims have horizontal 
Table 3. Decorative elements and motifs on utility ware rim sherds from the Wade site.

\begin{tabular}{|c|c|c|}
\hline Decorative element and motif & $\mathbf{N}$ & $\%$ \\
\hline Diagonal brushed & 3 & 4.2 \\
\hline Horizontal brushed & 6 & 8.5 \\
\hline Vertical brushed & 2 & 2.8 \\
\hline Diagonal incised lines on rim-diagonal brushed body & 1 & 1.4 \\
\hline Horizontal brushed-incised marks and lines & 4 & 5.6 \\
\hline Horizontal brushed, with diagonal tool punctates under lip & 1 & 1.4 \\
\hline $\begin{array}{l}\text { Horizontal brushed, with diagonal tool punctated rows } \\
\text { pushed through the brushing }\end{array}$ & 1 & 1.4 \\
\hline Horizontal brushed with tool punctated row pushed through the brushing & 4 & 5.6 \\
\hline Diagonal brushed, with tool punctated row under lip & 1 & 1.4 \\
\hline Tool punctated row at rim-body juncture and vertical brushed body & 1 & 1.4 \\
\hline Cross-hatched incised lines & 1 & 1.4 \\
\hline Diagonal incised lines & 6 & 8.5 \\
\hline Horizontal incised lines & 3 & 4.2 \\
\hline Horizontal and diagonal opposed incised lines & 1 & 1.4 \\
\hline Horizontal and vertical incised lines & 1 & 1.4 \\
\hline Opposed diagonal incised lines & 1 & 1.4 \\
\hline Vertical incised lines & 1 & 1.4 \\
\hline Incised circle and triangle filled with tool punctates & 1 & 1.4 \\
\hline Incised triangle filled with tool punctates & 3 & 4.2 \\
\hline Curvilinear incised band filled with tool punctates* & 1 & 1.4 \\
\hline Diagonal incised line above linear tool punctated row & 1 & 1.4 \\
\hline $\begin{array}{l}\text { Horizontal incised line and circular incised element filled } \\
\text { with tool punctates }\end{array}$ & 1 & 1.4 \\
\hline $\begin{array}{l}\text { Horizontal incised bands with diagonal tool punctates and } \\
\text { diagonal incised lines between bands }\end{array}$ & 1 & 1.4 \\
\hline Horizontal incised bands filled with crescent-shaped finger-nail punctates & 1 & 1.4 \\
\hline Horizontal incised band filled with tool punctates* & 6 & 8.5 \\
\hline Horizontal and vertical incised bands filled with punctates* & 2 & 2.8 \\
\hline Tool punctated row under lip and horizontal incised lines & 1 & 1.4 \\
\hline $\begin{array}{l}\text { Tool punctated row at rim-body juncture and diagonal } \\
\text { incised lines on body }\end{array}$ & 1 & 1.4 \\
\hline Crescent-shaped fingcrnail punctated rows & 1 & 1.4 \\
\hline Diagonal and linear tool punctated rows & 1 & 1.4 \\
\hline Linear tool punctated rows & 1 & 1.4 \\
\hline Tool punctated rows & 8 & 11.3 \\
\hline Tool punctated row under the lip & 3 & 4.2 \\
\hline Totals & 71 & 100.0 \\
\hline
\end{tabular}

*Washington Square Paneled 


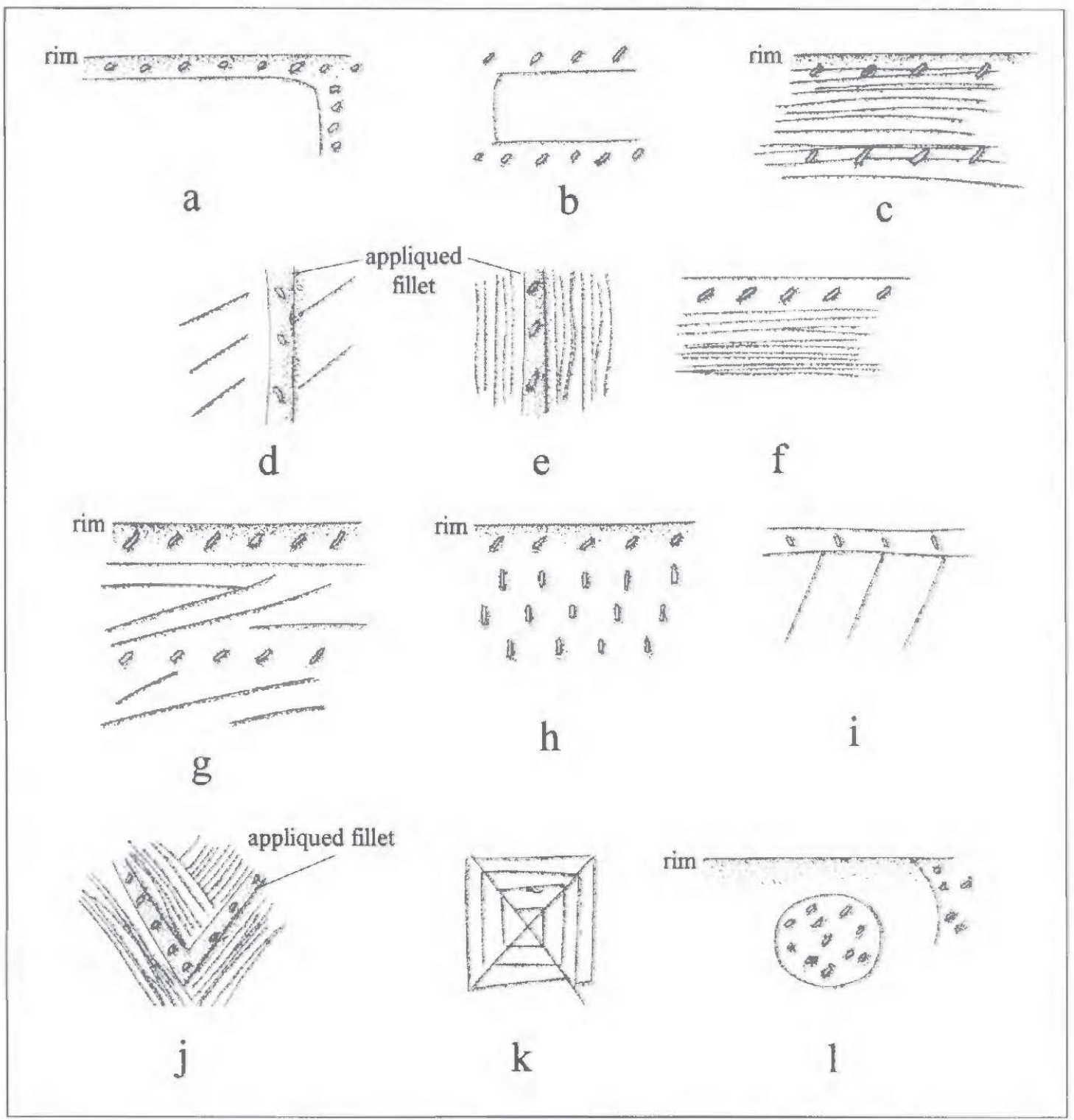

Figure 6. Drawings of selected sherd decorative elements: a-b, Washington Square Paneled; c, $\mathrm{f}$, brushed-punctated; d, appliqued-incised; e, j, brushed-appliqued; g, i, 1, incised-punctated; h, punctated; $\mathrm{k}$, incised.

interlocking incised scrolls with upper, lower, and vertical incised bands filled with tool punctates. This particular decorative style on the rims from these vessels has a considerable distribution on Middle Caddo (ca. A.D. 1200-1450) period sites in the mid-Sabine River basin and tributaries (Gadus et al. 2006; Perttula and Nelson 2013; Walters 2008) as well as contemporaneous Caddo sites in the Angelina River basin (see Hart 1982; Perttula et al. 2010).

While incised triangles filled with tool punctates are notable in the incised-punctated rims from the Wade site (see Table 3 and Figure 5i), there is at least one body sherd with a circular incised element filled with tool punctates as well as a rim sherd with punctate-filled triangles and circles (see Figures $5 \mathrm{c}$ and 61 ). Another has a set of curvilinear or arcing incised lines with an overlying series of linear tool punctates.

One of the punctated rims has crescent-shaped fingernail punctates (see Table 3), and may be from a Weches Fingernail Impressed jar (see Suhm and Jelks 1962:Plate 77); a rim sherd from another Weches 
Fingernail Impressed jar has horizontal incised bands filled with crescent-shaped fingernail punctates. Other rims have only tool punctates that are in rows on the rim (see Figure 6h), beginning under the vessel lip and extending to the rim-body juncture.

There are several other notable decorative elements on the utility ware body sherds. Two body sherds have straight appliqued fillets that divide panels with either parallel brushed-incised marks and lines or diagonal incised lines pitched in the same direction (see Figure 6d-e). A third body sherd (perhaps from a Pease Brushed-Incised vessel) has parallel brushed-incised marks and lines with a row of tool punctates pushed through the brushing, while another has parallel brushed-incised marks and lines divided by an alternating set of straight appliqued fillets and tool punctated rows pushed through the brushing. Another body sherd has a diagonal appliqued ridge that overlies a field of parallel brushing marks, while grog and bone-tempered jar body sherds have opposed diagonal appliqued fillets with surrounding brushing inarks pitched in opposite directions (see Figures $5 \mathrm{~d}$ and $6 \mathrm{j}$ ).

The fine ware rims include 22 sherds from vessels with engraved elements and motifs and one rim sherd (either a bowl or a carinated bowl) decorated only with a hematite-rich red slip on both interior and exterior surfaces (Table 4). The engraved rims are stylistically diverse, with both simple lines and geometric elements - diagonal (Figure $7 \mathrm{~g}$ ), horizontal (see Figure 5j), opposed diagonal, and vertical - on the rims of carinated bowls as well as bracket (see Figure 7j), concentric semi-circle (see Figures $5 \mathrm{~b}$ and $7 \mathrm{l}$ ), excised triangles and excised pendant triangles, rectangles, and a scroll element. The one rim with a scroll has a panel created with horizontal engraved lines, and on the panel is part of a slanted scroll and possibly part of a circle element; there is no apparent upper and lower scroll fill zone on this sherd, suggesting it is not from a Ripley Engraved vessel. Two rims are from Washington Square Paneled vessels (see Hart 1982; Perttula et al. 2010; Perttula and Nelson 2013) with horizontal engraved lines creating narrow bands filled with small excised punctations; this is in addition to the numerous incised-punctated Washington Square Paneled rim sherds listed in Table 3 and illustrated in Figure 6a-b. Another rim with hatched and cross-hatched brackets

Table 4. Decorative elements and motils on fine ware rim sherds from the Wade site.

\begin{tabular}{lrr}
\hline Decorative element and motif & $\mathrm{N}$ & $\%$ \\
\hline Cross-hatched and excised brackets & 1 & 4.3 \\
Diagonal engraved lines & 1 & 4.3 \\
Diagonal lines and concentric semi-circles & 1 & 4.3 \\
Horizontal engraved lines & 6 & 26.1 \\
Horizontal engraved lines and punctated band & 8.7 \\
Horizontal engraved lines, excised triangles, and cross-hatched zone & 1 & 4.3 \\
Horizontal engraved lines and small excised pendant triangles & 2 & 8.7 \\
Horizontal and diagonal band of engraved lines & 1 & 4.3 \\
Horizontal and diagonal engraved lines & 2 & 8.7 \\
Horizontal lines and rectangle element & 1 & 4.3 \\
Horizontal lines and scroll element & 1 & 4.3 \\
Horizontal hatched zone & 1 & 4.3 \\
Opposed diagonal engraved lines & 1 & 4.3 \\
Vertical engraved lines & 1 & 4.3 \\
Red-slipped, interior and exterior surfaces & & 4.3 \\
\hline Totals & 1 & 100.0 \\
\hline
\end{tabular}

*Washington Square Paneled 


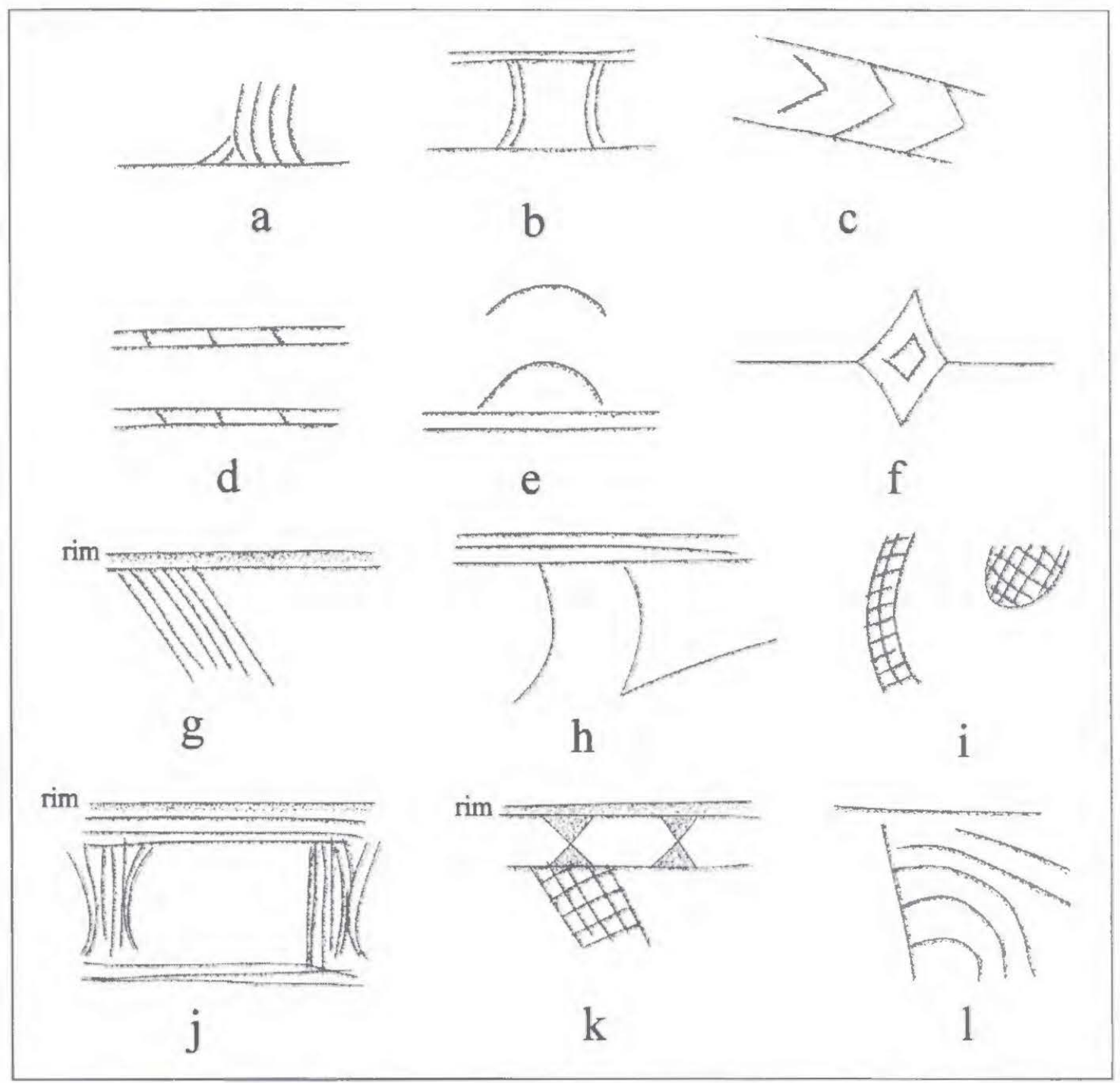

Figure 7. Drawings of selected engraved elements on rim and body sherds: $g, j-1$, rim sherds; a-f, $\mathrm{h}-\mathrm{i}$, body sherds.

has a distinctive Redwine mode lip treatment (see Figures 5a and 7j; see also Walters 2010). Such lip treatment has been documented in both utility ware and fine ware assemblages in the Sabine, Big Cypress, and Angelina-Neches drainage basins in East Texas.

Distinctive engraved body sherds include diagonal opposed lines, narrow hatched and cross-hatched lines, straight and curvilinear zones and circles (see Figure 7a, d, i), open circles, engraved and excised brackets (on carinated sherds and bottles), narrow panels with stepped lines (see Figure 7c), and parallel lines with attached semi-circles (see Figure 7e). There is also one engraved diamond central scroll element on a body sherd (see Figure 7f) that may be from a Ripley Engraved, var. McKinney vessel.

There are only three engraved bottle sherds ( $2.9 \%$ of all the engraved sherds) with sets of curvilinear lines in the fine ware assemblage from the Wade site. Another bottle sherd has part of a straight engraved line and an excised bracket

Only one engraved sherd ( $1.0 \%$ of all the engraved sherds) has a white pigment rubbed in the engraved lines. 


\section{Ceramic Pipe}

A Middle Caddo period style L-shaped clay elbow pipe stem sherd is in the Wade site ceramic assemblage. This style of elbow pipe has been found in a number of ca. A.D. 1200-1450 Caddo habitation sites and burials in the Sabine and Neches-Angelina river basins. In general, elbow pipes began to be made after ca. A.D. 1350 in East Texas and elsewhere in the Caddo area.

\section{Lithic Assemblage}

There is one Late Archaic style quartzite Yarbrough dart point from the Wade site, along with a quartzite Wells point and a gray chert Ellis point, and a ferruginous sandstone gouge, as well as quartzite, petrified wood, and gray chert Gary points $(n=5)$ (Figure 8c) and two (brown chert and quartzite, Figure 8e) Kent points that evince Woodland period use. There are also two petrified wood biface preforms, a gray chert bifacial perforator, a gray chert expedient flake tool, and a gray chert end/side scraper. Ground stone tools from the Late Archaic and Woodland period components includes a ferruginous sandstone abrader, a ferruginous sandstone grinding slab fragment, a hematite mano, a quartzite mano and pitted stone, and a quartzite hammerstone.

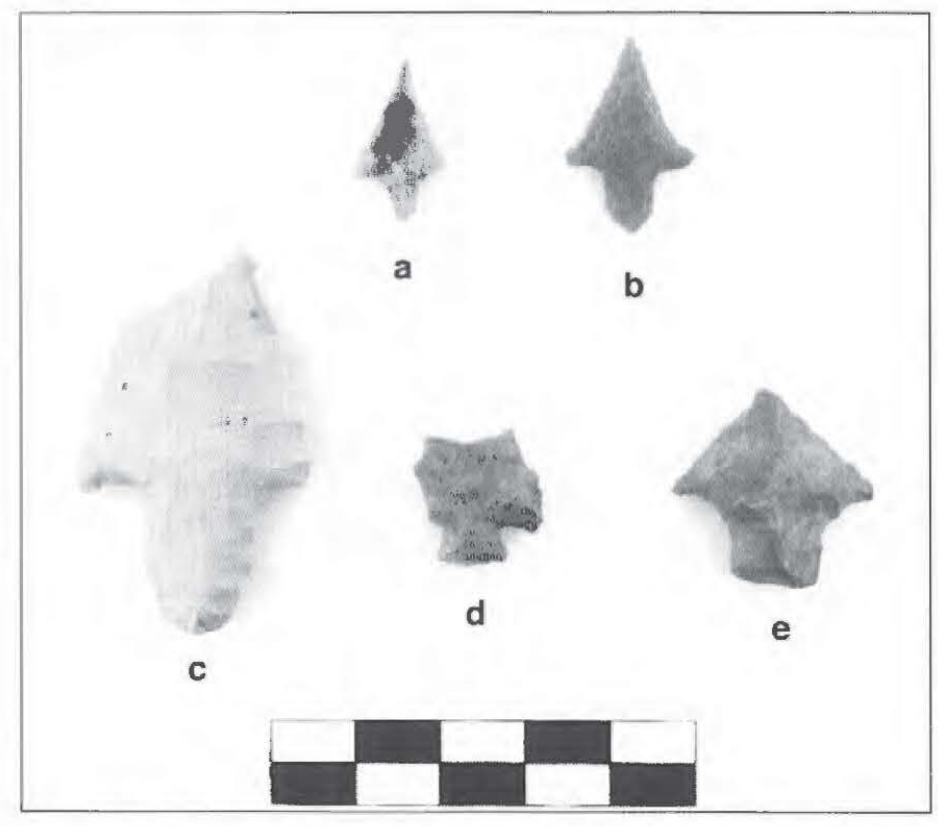

Figure 8. Projectile points from the Wade site: a, Perdiz arrow point; b, Bonham arrow point; c, Gary dart point; d, Scallorn arrow point; e, Kent dart point.

Arrow points from the Wade site include a quartzite Scallorn (see Figure 8d), a petrified wood Bonham (see Figure 8b), and a gray chert Perdiz (see Figure 8a), all indicative of aboriginal use by and after ca. A.D. 700. In the Caddo component there are also a greenstone celt fragment, two quartzitic sandstone celt fragments, a celt preform of the same material, and a single celt resharpening flake (Figure 9). These materials have their source in the Ouachita Mountains of southeastern Oklahoma.

\section{Other Recovered Artifacts}

There are also numerous pieces of unburned mussel shell valves, turtle bones, deer phalanges, as well as chunks of daub, burned clay, and a clay coil in the archaeological deposits at the site. 


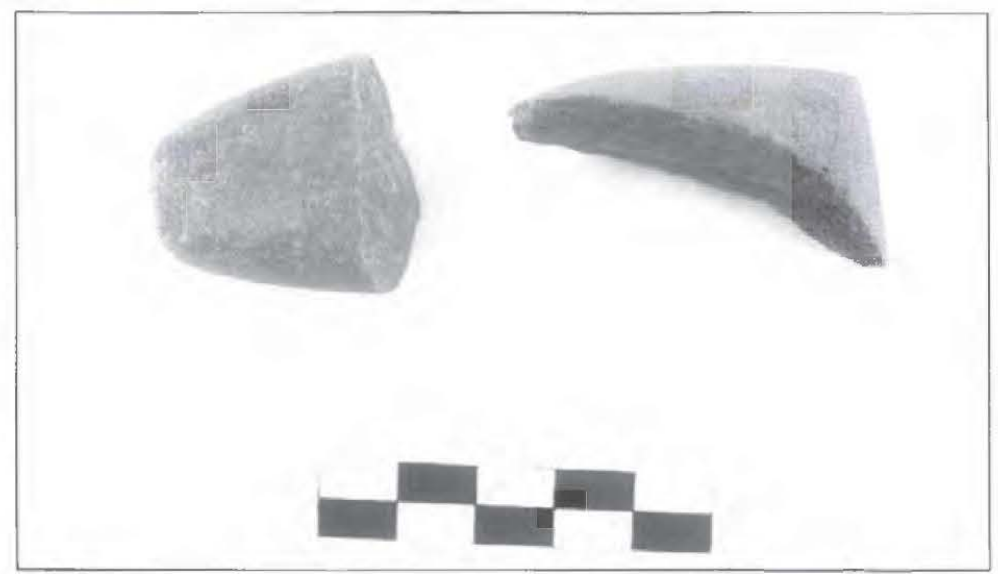

Figure 9. Celt fragments from the Wade site.

THE ESTES SITE (GC-49)

The Estes site artifact assemblage was presumably collected by Jones from the surface of the site after it had been plowed. There are no available records or notes that indicate Jones conducted any excavations at this site.

\section{Ceramic Assemblage}

There is a large assemblage of Caddo ceramic vessel sherds $(n=1097)$ from surface collections at the Estes site. This includes 410 plain rim, body, and base sherds, and 687 decorated utility ware $(n=585)$ and fine ware $(\mathrm{n}=102)$ sherds (Table 5). The P/DR is 0.60 .

As with the previously discussed Wade site ceramic assemblage, the Estes site ceramic sherds are also predominantly from grog-tempered vessels. Approximately $13.9 \%$ of the sherds are from vessels tempered with crushed burned bone. The highest proportion of burned bone use is in the fine wares (17.6\%) (Table 6).

Almost $30 \%$ of the rims in the assemblage are from plain ware vessels, compared to about $58 \%$ from utility wares, and $13 \%$ from fine ware vessels (see Table 5). With respect to the decorated sherds, approximately $85 \%$ of the rim and body sherds are from utility wares, especially sherds from brushed, brushed-incised, incised, punctated, and brushed-punctated vessels (Figures 10-12). As a group, $40.8 \%$ of all the sherds from the Estes site have brushing marks, either as the sole decoration or in combination with appliqued, incised, or punctated elements. The remaining 15\% are sherds from engraved and engraved-punctated fine wares (see Table 5). In addition to the many ceramic sherds, a single clay coil and a piece of daub were also in the assemblage.

Decorative elements and motifs on rim sherds from utility ware vessels at the Estes site are listed in Table 7. The most common decorative treatments on these vessels are horizontal brushing $(13.3 \%$ of the utility ware rims), horizontal brushing on the rim below a row of diagonal tool punctates (see Figure $10 \mathrm{~h}-\mathrm{j}$, $13.3 \%)$, and horizontal brushed-incised marks and lines (12.2\%). 
Table 5. Ceramic sherd assemblage from the Estes site.

\begin{tabular}{|c|c|c|c|c|c|}
\hline Ware & Rim & Body & Base & $\mathrm{N}$ & $\%$ \\
\hline Plain ware & 44 & 319 & 47 & 410 & 37.4 \\
\hline \multicolumn{6}{|l|}{ Utility ware } \\
\hline Appliqued & - & 4 & - & 4 & 0.4 \\
\hline Appliqued-punctated & - & 2 & - & 2 & 0.2 \\
\hline Brushed & 15 & 259 & - & 274 & 25.0 \\
\hline Brushed-appliqued & - & 8 & - & 8 & 0.7 \\
\hline Brushed-appliqued-incised & - & 2 & - & 2 & 0.2 \\
\hline Brushed-incised & 21 & 97 & - & 118 & 10.8 \\
\hline Brushed-punctaled & 23 & 19 & - & 42 & 3.8 \\
\hline Grooved & - & 1 & - & 1 & 0.1 \\
\hline Incised & 13 & 35 & - & 48 & 4.4 \\
\hline Incised-appliqued & - & 2 & - & 2 & 0.2 \\
\hline Incised-punctated & 7 & 16 & - & 23 & 2.1 \\
\hline Incised-punctated-brushed & 2 & 1 & - & 3 & 0.3 \\
\hline Lip notched & 1 & - & - & 1 & 0.1 \\
\hline Pinched & - & 4 & - & 4 & 0.4 \\
\hline Punctated & 8 & 45 & - & 53 & 4.8 \\
\hline \multicolumn{6}{|l|}{ Fine ware } \\
\hline Engraved & 16 & 82 & - & 98 & 9.0 \\
\hline Engraved-punctated & 4 & - & - & 4 & 0.4 \\
\hline Totals & 154 & 896 & 47 & 1097 & 100.0 \\
\hline
\end{tabular}

Table 6. Use of bone temper in the ceramic sherds from the Estes site.

\begin{tabular}{lcc}
\hline Ware & No. of sherds & \% bone-temper \\
\hline Plain ware & 410 & 13.0 \\
Utility ware & 585 & 14.0 \\
Fine ware & 102 & 17.6 \\
\hline lotals & 1097 & 13.9 \\
\hline
\end{tabular}




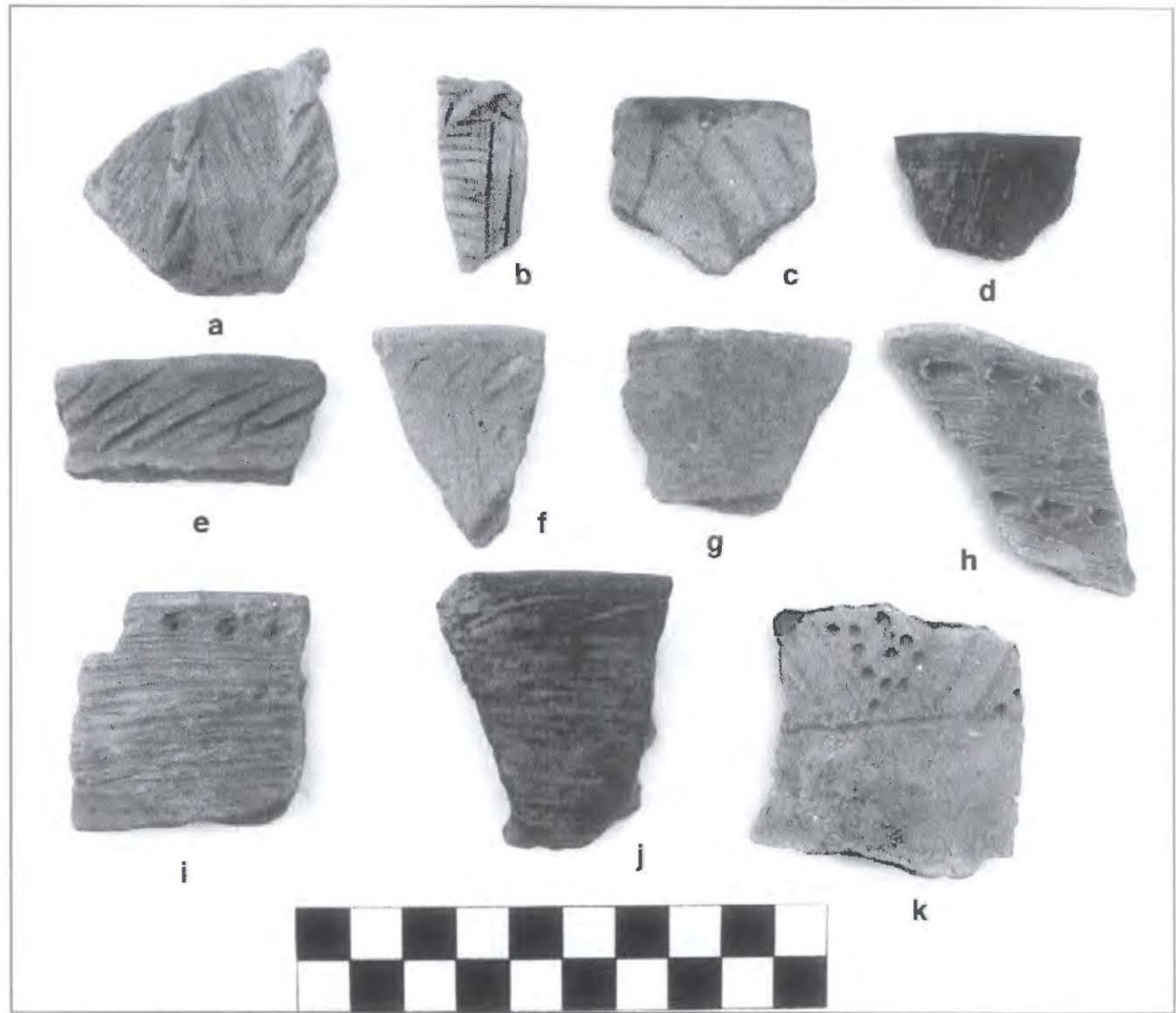

Figure 10. Selected utility wares in the Estes site ceramic assemblage: a, brushed-appliquedincised; b, incised-appliqued; c-e, incised; f, incised-punctated; g, punctated (cf. Washington Square Paneled); h-j, brushed-punctated; k, incised-punctated.

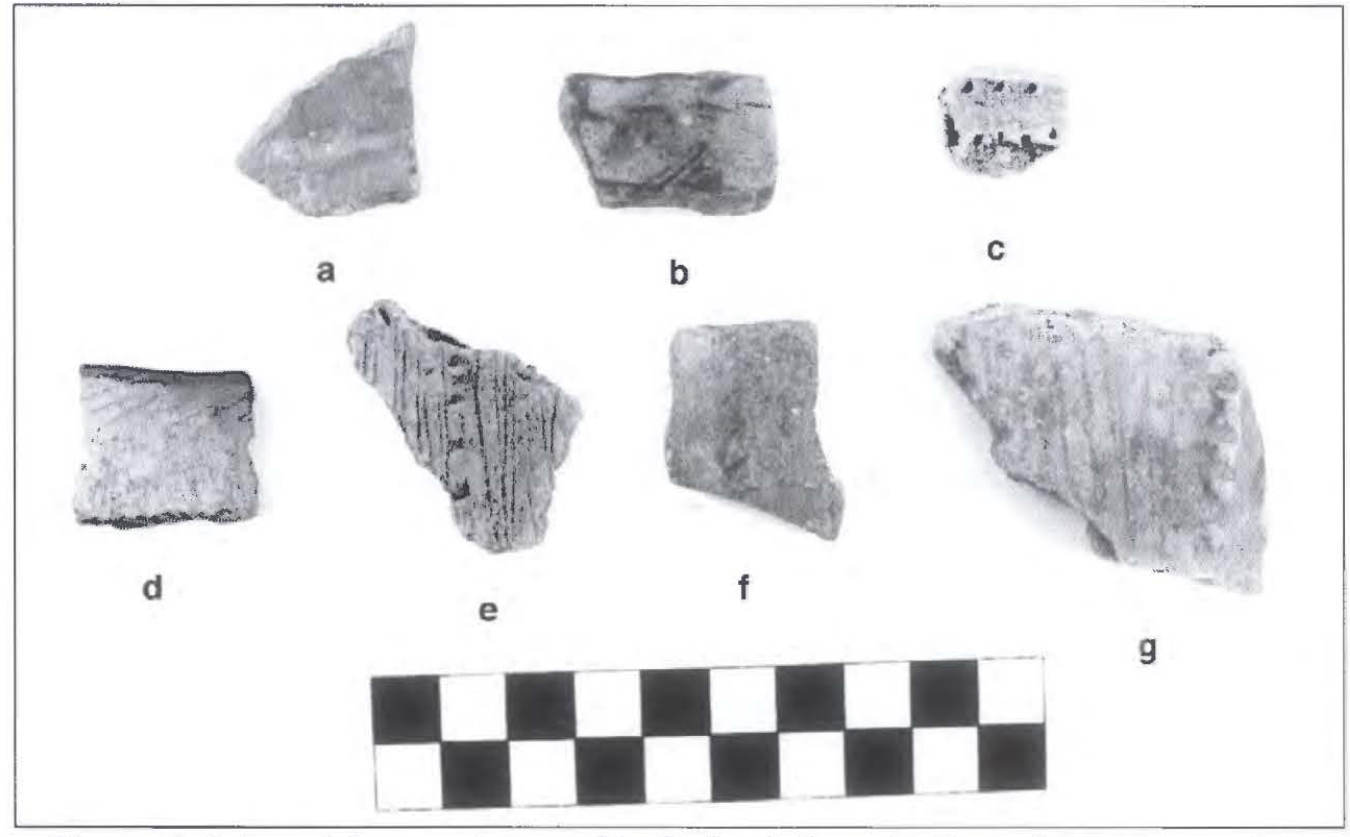

Figure 11. Selected decorated rim and body sherds from the Estes site: a, engraved; b, incised-punctated; c, punctated; d, brushed-punctated; e, incised-appliqued; f-g, brushed-appliqued. 


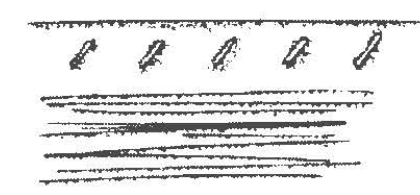

a

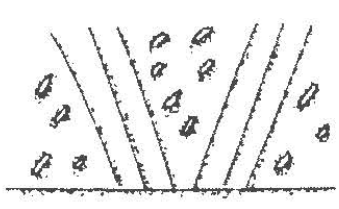

b

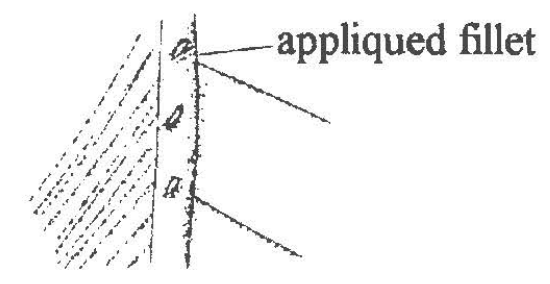

c

Figure 12. Drawings of selected decorative elements in utility wares: $a$, brushed-punctated; $b$, incisedpunctated; c, brushed-incised-appliqued.

Table 7. Decorative elements and motifs on utility ware rim sherds from the Estes site.

\begin{tabular}{|c|c|c|}
\hline Decorative element and motif & $\mathrm{N}$ & $\%$ \\
\hline Diagonal brushing marks & 1 & 1.1 \\
\hline Horizontal brushing marks & 12 & 13.3 \\
\hline Horizontal brushed on rim and vertical brushed body & 1 & 1.1 \\
\hline Vertical brusbing marks & 1 & 1.1 \\
\hline Horizontal brushed rim-vertical and diagonal incised lines on body & 1 & 1.1 \\
\hline Horizontal brushed-incised marks and lines & 11 & 12.2 \\
\hline $\begin{array}{l}\text { Horizontal brushed-incised on rim and vertical brushed-incised } \\
\text { on body }\end{array}$ & 8 & 8.9 \\
\hline Horizontal incised lines on rim and diagonal brushed body & 1 & 1.1 \\
\hline Horizontal brushing marks below a row of diagonal tool punctates & 12 & 13.3 \\
\hline Horizontal brushed below row of tool punctates under lip & 6 & 6.7 \\
\hline $\begin{array}{l}\text { Horizontal brushing marks and tool punctated row at rim- } \\
\text { body juncture-vertical brushing on body }\end{array}$ & 1 & 1.1 \\
\hline Horizontal brusbed with tool punctated rows under lip and mid-rim & 1 & 1.1 \\
\hline Diagonal tool punctates under lip and vertical brushed & 1 & 1.1 \\
\hline $\begin{array}{l}\text { Tool punctated row at rim-body jencture and vertical } \\
\text { brushed body }\end{array}$ & 1 & 1.1 \\
\hline Tool punctated row under lip and vertical brushed body & 1 & 1.1 \\
\hline Diagonal incised lines & 4 & 4.4 \\
\hline Diagonal-horizontal incised lines & 4 & 4.4 \\
\hline Diagonal incised lines on the rim and vertical incised on body & 1 & 1.1 \\
\hline Horizontal incised lines & 1 & 1.1 \\
\hline Opposed diagonal incised lines & 3 & 3.3 \\
\hline $\begin{array}{l}\text { Horizontal incised lines-diagonal linear tool punctates- } \\
\text { horizontal brushing on body }\end{array}$ & 1 & 1.1 \\
\hline $\begin{array}{l}\text { Tool punctated row under lip and horizontal incised and } \\
\text { brushed panel }\end{array}$ & 1 & 1.1 \\
\hline
\end{tabular}


Table 7. Decorative elements and motifs on utility ware rim sherds from the Estes site, cont.

\begin{tabular}{lll}
\hline Decorative element and motif & $\mathrm{N}$ & $\%$ \\
\hline Incised triangle filled with tool punctates & 2 & 2.2 \\
Tool punctated bands between horizontal incised lines & 2 & 2.2 \\
Diagonal tool punctates under lip-incised triangle filled with & 1 & 1.1 \\
tool punctates & 2 & 2.2 \\
Horizontal incised line and row of diagonal tool punctates & 1 & 1.1 \\
& & 1.1 \\
Lip notched & 1 & 2.2 \\
Circular tool punctated rows & 2 & 2.2 \\
Diagonal tool punctated row under lip & 2 & 2.2 \\
Tool punctate rows & 2 & 1.1 \\
Tool punctated row under lip and diagonal linear tool punctates & 1 & \\
Tool punctated row at rim-body juncture and random tool & & 100.0 \\
punctates on body & 90 & \\
\hline Totals & & \\
\hline
\end{tabular}

About $68 \%$ of the utility rim sherds have a brushed decoration, but this brushing occurs in several different ways on vessels: as the sole decorative element (16.6\%), usually horizontal brushing (Figures 13a-b and 14f), perhaps from Bullard Brushed jars; in combination with incised lines, sometimes together on the rim, or with one decorative method on the rim and the other on the body $(23.3 \%)$; in combination with punctations $(25.5 \%)$ of different forms, where the punctations are in various locations on the rim (see Figures I0f, $\mathrm{h}-\mathrm{j}, 11 \mathrm{~d}$, and 12a); or in combination with incised lines and tool punctated rows on the rim (2.2\%). Brushed sherds with portions of the rim and body preserved on them indicate that brushed jars have brushed bodies (vertical and diagonal marks, Figures 13b and 14a-b, d-e), opposed brushing marks (Figure 14c), or with diagonal incised bodies (see Table 7). Brushed body sherds sometimes occur with panels defined by straight appliqued fillets (see Figure $11 \mathrm{f}-\mathrm{g}$ ).

One body sherd has a straight appliqued fillet dividing a field of diagonal brushing marks from a field of diagonal incised lines pitched in the opposite direction (see Figures 10a and 12c). Another has parallel brushing marks with an overlying straight appliqued fillet and overlying parallel incised lines (see Figure 11e).

Approximately $14 \%$ of the utility ware rim sherds from the Estes site have simple geometric incised line elements and motifs, featuring primarily diagonal lines pitched in various directions (see Figure 10c-e and Table 7). Incised body sherds have the same decorative elements (see Figure 12b). Incised-appliqued body sherds have single short appliqued ridges nested in a series of opposed incised lines (see Figure 10b). Incised-punctated rim and body sherds are probably from Maydelle Incised vessels (see Suhm and Jelks 1962 ) as they have a series of diagonal incised lines and incised triangles on the rim filled with tool punctations (see Figure 10l). Other body sherds simply have rows of tool punctations and incised lines in various directions (see Figure 11b).

Some of the utility ware rim sherds have rows of different shapes of tool punctations on the rim, typically beginning in a row under the vessel lip and ending with a row at the rim-body juncture (see Table 7 and Figure $11 \mathrm{c}$ ). Punctated rims comprise $8.9 \%$ of the utility ware rims at the Estes site. One rim and body sherd indicates that vessel bodies were sometimes covered with randomly-placed tool punctates. 


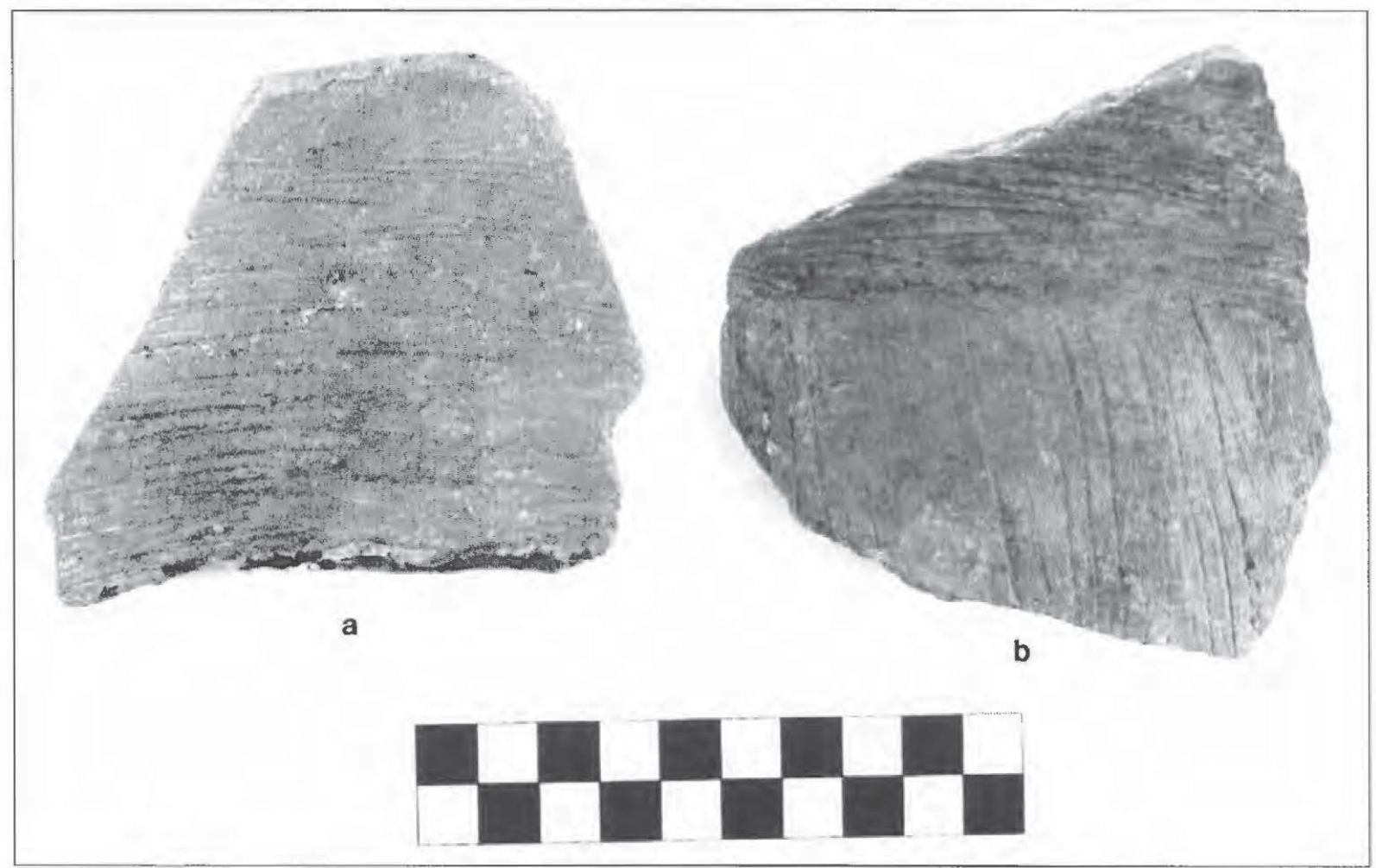

Figure 13. Brushed rim and lower rim-body sherds from the Estes site: $a$, horizontal brushed rim; b, horizontal brushed rim and vertical brushed body.

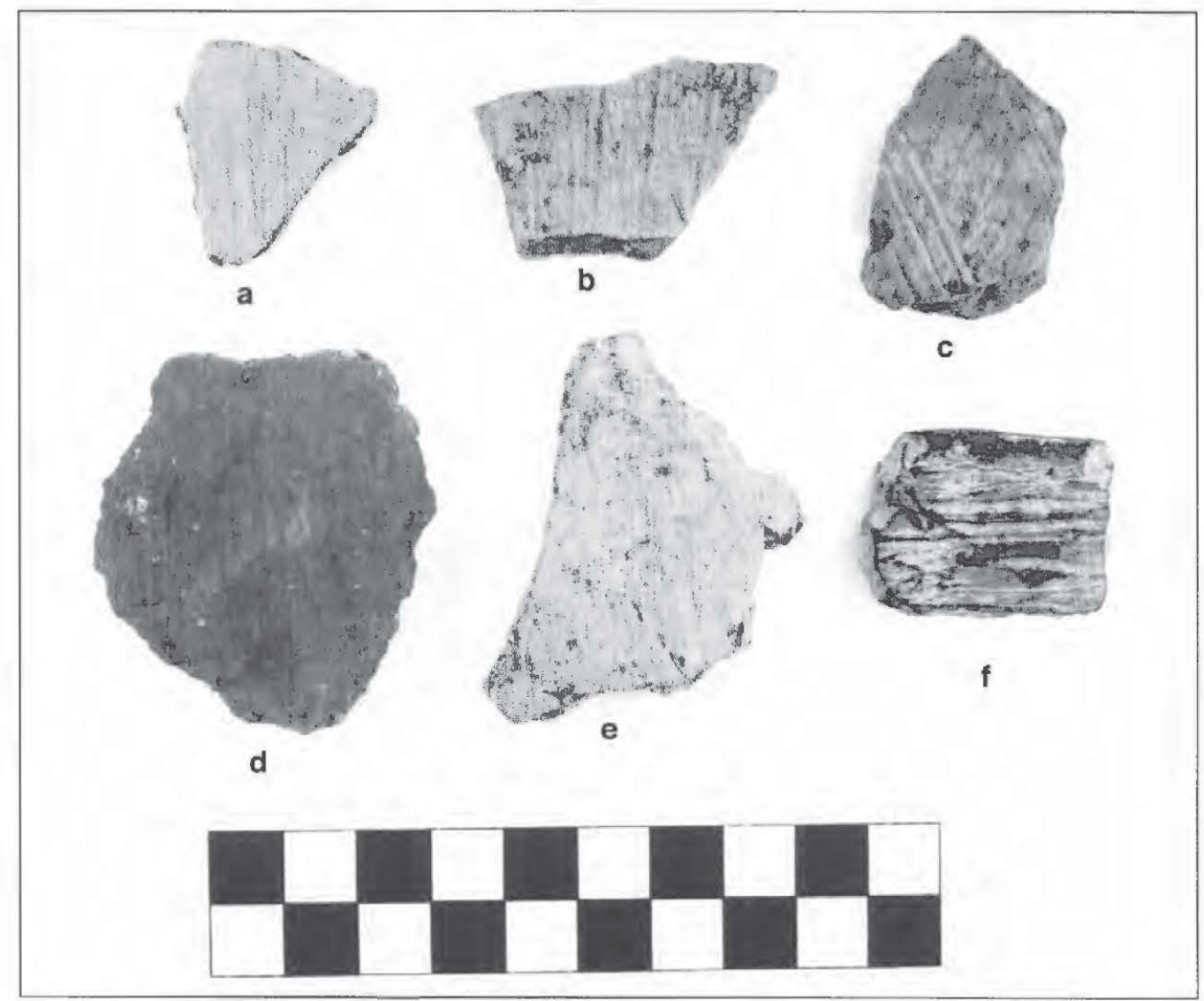

Figure 14. Brushed rim and body sherds from the Estes site: a-b, d-e, parallel brushed; c, opposed brushed; $\mathrm{f}$, horizontal brushed. 
Finally, a rare decorative element on utility wares is lip notching. One rim sherd from the Estes site is notehed on the lip (see Table 7).

The fine ware rims are from both engraved and engraved-punctated vessels (Table 8); a few of the engraved sherds have white $(n=1)$ (Figure 15e) or red pigment $(n=2)$ rubbed in the engraved lines; about 3\% of the engraved line wares have a preserved pigment. The four engraved-punctated rims (Figures $15 \mathrm{e}-\mathrm{f}$ and 16b) are from the engraved variety of Washington Square Paneled carinated bowls (see Hart 1982: Perttula et al. 2010; Perllula and Nelson 2013), which appear in ca. A.D. 1200-1450 contexts in sites in both the mid-Sabine and Angelina River basins of East Texas. The majority of the other engraved rims have diagonal. horizontal, or vertical lines as decorative elements, along with several with narrow hatched zones (Figure $15 \mathrm{~d}$ ), hatched and cross-hatched ladders (Figures $15 \mathrm{~g}$ and $16 \mathrm{~h}$ ), and hatched triangles (Figure $16 \mathrm{c}$ ). Three other rims either have engraved semi-circles or sets of near vertical arcing lines extending from a horizontitl engraved line above the carination.

Table 8. Decorative elements and motifs on fine ware rim sherds from the Estes site.

\begin{tabular}{|c|c|c|}
\hline Decorative element and motif & $N$ & $\%$ \\
\hline Diagonal hatched zones & 1 & 5.0 \\
\hline Horizontal hatched zone & 1 & 5.0 \\
\hline Horizontal engraved lines & 4 & 20.0 \\
\hline Horizontal and diagonal engraved lines & 1 & 5.0 \\
\hline Horizontal and diagonal opposed lines & 1 & 5.0 \\
\hline Horizontal engraved line and hatched triangle element & 1 & 5.0 \\
\hline Horizontal engraved lines and hatched triangles and ladders & 1 & 5.0 \\
\hline Horizontal engraved line and near vertical arcing lines & 1 & 5.0 \\
\hline Horizontal engraved lines and semi-circle & 2 & 10.0 \\
\hline Vertical engraved lines & 2 & 10.0 \\
\hline Vertical cross-hatched engraved zone & 1 & 5.0 \\
\hline Interlocking horizontal engraved scroll and punctated rows* & 4 & 20.0 \\
\hline Totals & 20 & 100.0 \\
\hline
\end{tabular}

:Washington Square Paneled

Notable by their absence in the cngraved fine ware rims from the Estes site are sherds with any of the decorative elements seen on mid-Sabine River post-ca. A.D. 1450 Ripley Engraved vessels (see Fields and Gadus 2012:433-447), particularly scrolls, diamonds. circles with swastikas or crosses, or pendant triangles. This would certainly seem to suggest that the principal Caddo occupation of the Estes site occurred in the Middle Caddo period.

Anong the engraved body sherds in the fine wares from the Estes site are at number with simple geometric decorative elements, such as straight, diagonal, parallel, or opposed engraved lines (see Figures $15 \mathrm{~b}$ and 16d). There is one body sherd with parallel engraved lines and small excised triangles; this is probably from another Washington Square Paneled vessel. Other carinated bowl sherds have narrow engraved zones with hatched or cross-hatched lines (see Figures $11 \mathrm{a}, 15 \mathrm{a}, \mathrm{c}-\mathrm{d}, \mathrm{g}, \mathrm{k}-\mathrm{l}$, and $16 \mathrm{~g}$ ) and hatched triangles. Engraved bottle sherds $(n=11)$ have sets of curvilinear or parallel lines (see Figures $15 \mathrm{~h}, \mathrm{j}$ and $16 \mathrm{e}$ ), but one has a large negative S or SZ (see Fields and Gadus 2012:Figure 6.1) element outlined by closely-spaced 


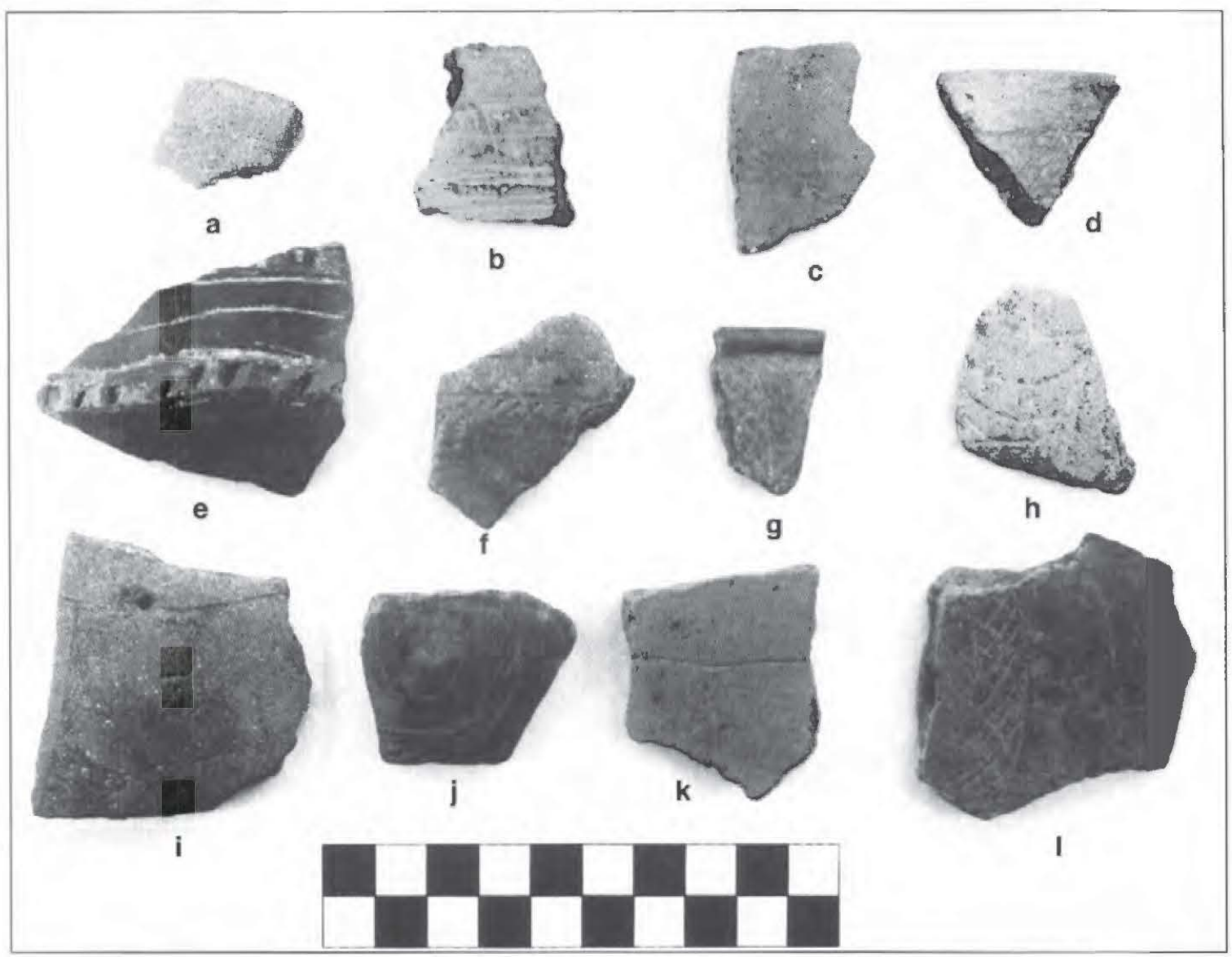

Figure 15. Engraved rim and body sherds from the Estes site: a-c, k-1, body sherds; d, g, rim sherds; e-f, Washington Square Paneled carinated bowl sherds; $h-j$, bottle sherds.

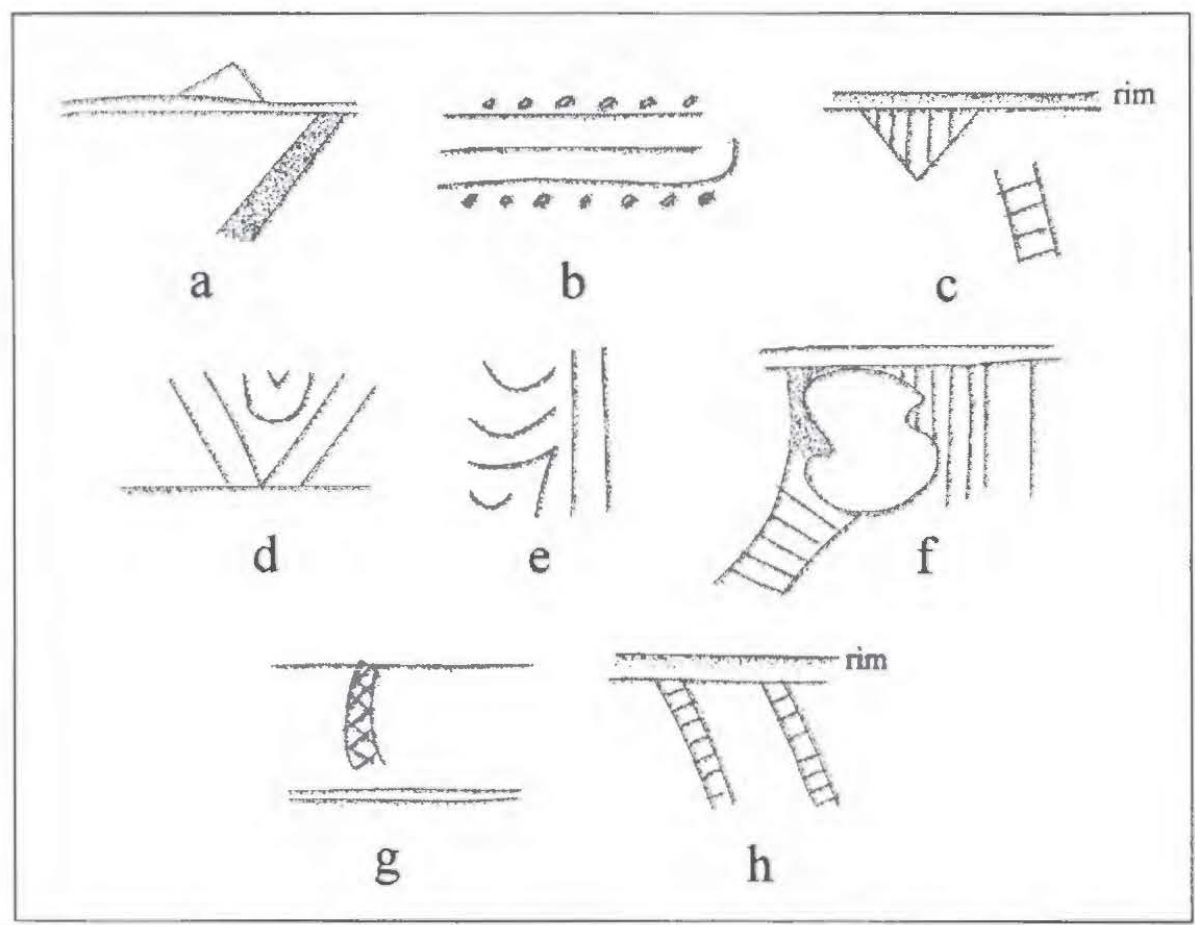

Figure 16. Drawings of selected engraved decorative elements: a, d-g, body sherds; b, Washington Square Paneled carinated bowl sherd; c, h, rim sherds. 
vertical engraved lines, an excised zone, and portions of a narrow hatched zone (see Figures $15 \mathrm{i}$ and $16 \mathrm{f}$ ), and another (with red pigment) has diagonal excised zones and an open triangle element (see Figure 16a).

\section{Lithic Assemblage}

There is evidence in the chipped stone artifacts of Late Archaic use of the Estes site. This includes a ferruginous sandstone gouge and a straight stemmed dart point manufactured from a grayish-red chert, as well as examples of Ellis and Yarbrough points. A single Gary, var. Camden dart point of quartzite and a Kent dart point of petrified wood are indicative of a late Woodland period use (ca. A.D. 200-700) (see Schambach 1982, 1998).

The post-ca. A.D. 800 Caddo lithic artifacts from the site include a red chert Alba point (Figure 17c), a gray chert Bonham-Perdiz (Figure 17b) - which is likely associated with the principal Middle Caddo component at the site - and a quartzite Maud point (Figure 17a) of post-A.D. 1550 age. There are also expedient flake tools $(n=7)$, a chert drill, and scrapers $(n=2)$, as well as a greenstone celt fragment (Figure 18).

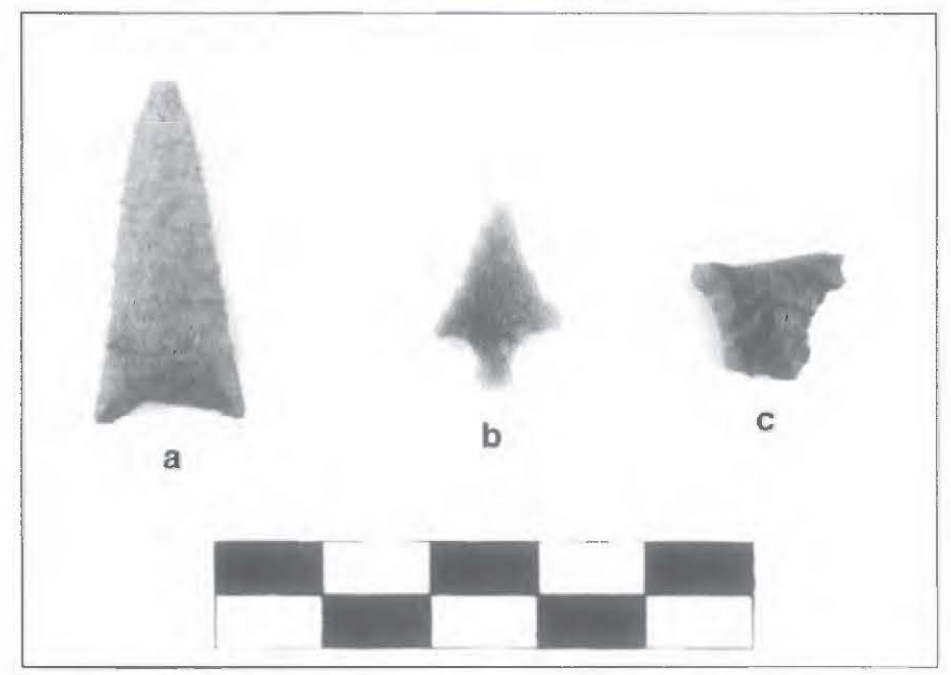

Figure 17. Arrow points from the Estes site: $a$, Maud; b, Bonham-Perdiz; c, Alba.

\section{SUMMARY AND CONCLUSIONS}

The Wade and Estes sites are located in the mid-Sabine River basin in Gregg County, in the East Texas Pineywoods, in the general area of the city of Longview. Both sites were found and investigated by Buddy C. Jones more than 50 years ago. He obtained surface collections of artifacts - mainly plain and decorated sherds from ancestral Caddo occupations - from both sites, and carried out limited excavations at the Wade site in 1961. That work identified a variety of features, mainly post holes and pits, from an ancestral Caddo house structure as well as associated midden deposits. Chipped stone artifacts found at both sites also show that the sites were used to some limited extent during both the Late Archaic (ca. 5000-2500 years B.P.) and Woodland (ca. 2500-1200 years B.P.) periods.

The work at both sites by Jones resulted in the collection of large assemblages of decorated utility ware and fine ware rim and body sherds (687-794 sherds per site). The stylistic character of these sherds is useful in assessing the age of the Caddo occupations, and the historical relationships evidenced in the decorative elements and motifs that speak of cultural transmission and stylistic change and continuity in the decoration of Caddo vessels in the mid-Sabine River basin. As best as can be determined from the decorated sherd 


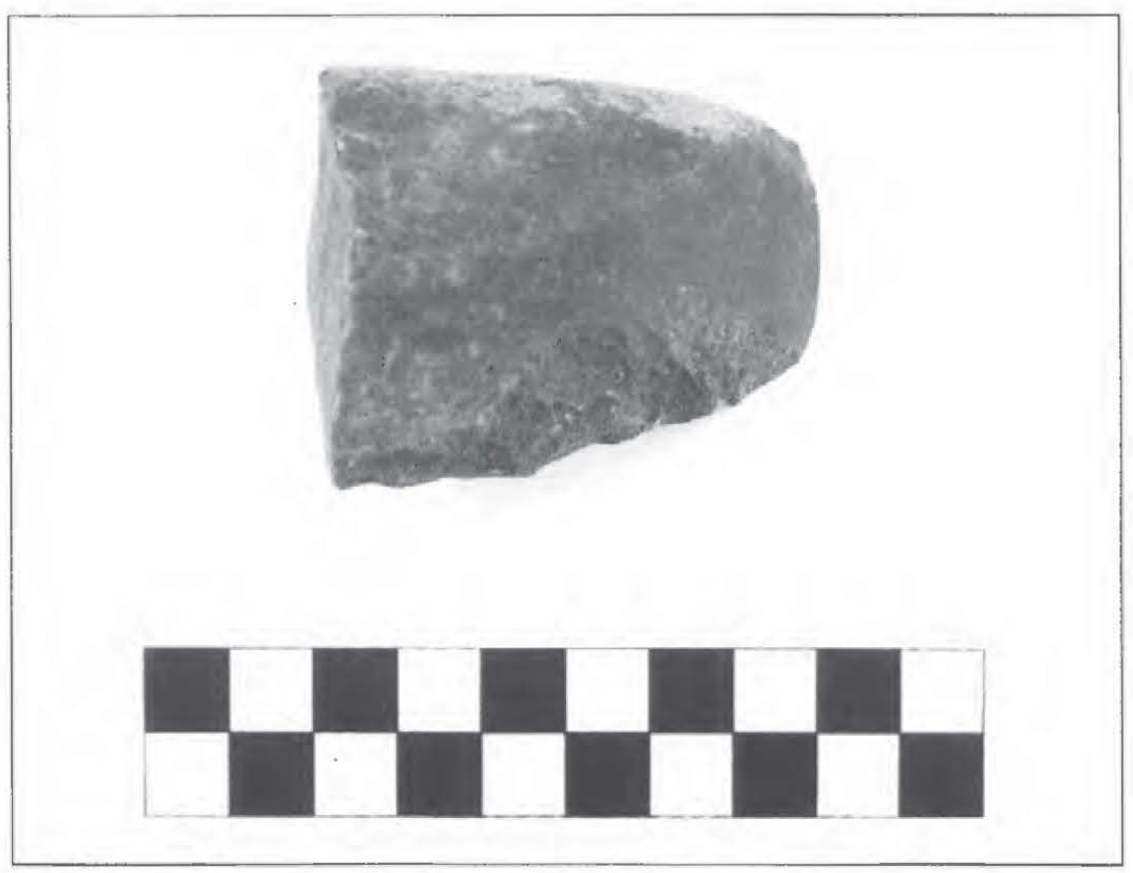

Figure 18. Greenstone celt fragment from the Estes site.

assemblages and a clay pipe from the Wade site, but in the absence of radiocarbon dates from the sites, the principal ancestral Caddo domestic settlements at both sites predate ca. A.D. 1450, but possibly they both date between ca. A.D. 1350-1450. The engraved fine wares, and the incised-punctated variant of Washington Square Paneled at the Wade site. are not stylistically similar to the post-A.D. 1450 fine wares documented from the Pine Tree Mound community (see Fields and Gadus 2012) a few miles downstream on a tributary to the Sabine River. Instead they are more like ceramic assemblages on Middle Caddo period (ca. A.D. 1200-1450) sites in the mid-Sabine and Angelina River basins (cf. Gadus et al. 2006; Hart 1982; Perttula and Nelson 2013; Walters 2008, 2010), and it is likely that various Caddo communities in these areas had close social and cultural ties and established networks of contact and cultural transmission of ideas and practices.

Rim and body sherds with brushing marks as the decorative treatment dominate the decorated sherd assemblages from both the Wade and Estes sites (Table 9). At the Wade site, for example, $50 \%$ of the decorated sherds have brushing marks - either as the sole decorative element or in combination with other decorative methods such as incised lines or punctations - and $57 \%$ of the utility wares have brushing marks. The proportion of brushed sherds is even higher at the Estes site: $65 \%$ of all the decorated sherds have brushing marks, and $76 \%$ of the utility wares have brushed decorations. These differences may suggest that the ancestral Caddo component at the Estes site is a bit younger than that at the Wade site, given temporal trends (i.e., increasing proportions of brushed sherds as assemblages get progressively younger in age) in the relative popularity of brushing in decorated sherd assemblages in the mid-Sabine River region.

The differences between the two sites in the amount of sherds with brushing lies particularly with an increased percentage of sherds with brushed-incised and brushed-punctated decorative elements at the Estes site when compared to the Wade site assemblage (Table 9). In other respects, utility wares with incised ( $20.2 \%$, including sherds with incised and other decorative elements on the same rim and body sherds) and punctated $(16.2 \%)$ decorative elements are more common in the Wade site assemblage when compared to the Estes assemblage: only $11.0 \%$ and $7.7 \%$, respectively (see Table 9). Sherds from fine ware vessels are equally rare in both sites: $13.4 \%-13.7 \%$. However, red-slipped sherds are present only at the Wade site and engraved-punctated Washington Square Paneled sherds are present only at the Estes site. At the Wade site, rim and body sherds from Washington Square Paneled vessels have both engraved-punctated and incisedpunctated decorative elements. 
Table 9. Comparison of the decorated sherd assemblages from the Wade and Estes sitc.

\begin{tabular}{|c|c|c|c|c|}
\hline \multirow[t]{2}{*}{ Ware } & \multicolumn{2}{|c|}{ Wade } & \multicolumn{2}{|c|}{ Estes } \\
\hline & $\mathrm{N}$ & $\%$ & $x$ & $\%$ \\
\hline \multicolumn{5}{|l|}{ Utility ware } \\
\hline Appliqued & 5 & 0.6 & 4 & 0.6 \\
\hline Appliqued-punctated & - & - & 2 & 0.3 \\
\hline Brushed & 275 & 34.7 & 274 & 40.0 \\
\hline Brushed-appliqued & 12 & 1.5 & 8 & 1.2 \\
\hline Brushed-appliqued-incised & 1 & 0.1 & 2 & 0.3 \\
\hline Brushed-incised & 78 & 9.8 & 118 & 17.2 \\
\hline Brushed-punctated & 26 & 3.3 & 42 & 6.1 \\
\hline Grooved & - & - & 1 & 0.1 \\
\hline Incised & 103 & 13.0 & 48 & 7.0 \\
\hline Incised-appliqued & 1 & 0.1 & 2 & 0.3 \\
\hline Incised-punctated & 54 & 6.8 & 23 & 3.3 \\
\hline Incised-punctated-brushed & 2 & 0.3 & 3 & 0.4 \\
\hline Lip notched & - & - & 1 & 0.1 \\
\hline Pinched & 2 & 0.3 & 4 & 0.6 \\
\hline Pinched-Punctated & 1 & 0.1 & - & \\
\hline Punctated & 128 & 16.2 & 53 & 7.7 \\
\hline \multicolumn{5}{|l|}{ Fine ware } \\
\hline Engraved & 103 & 13.0 & 98 & 13.1 \\
\hline Engraved-punclated & - & & 4 & 0.6 \\
\hline Red-slipped & 3 & 0.4 & & \\
\hline Totals & 794 & 100.0 & 687 & 100.0 \\
\hline
\end{tabular}

\section{ACKNOWLEDGEMENTS}

We thank Patti Haskins of the Gregg County Historical Commission for her help during the analysis of the archaeological material remains from the Wade and Estes sites. Lance Trask prepared the drawings of the decorated ceramic sherds from the sites. 


\section{REFERENCES CITED}

Fields, R. C. and E. F. Gadus (editors)

2012 Archeology of the Nadaco Caddo: The View from the Pine Tree Mound Site (4IHS1.5), Harrison County, Texas. 2 Vols. Reports of Investigations No. 164. Prewitt and Associates, Inc., Austin.

Gadus, E. F., R. C. Fields, J. K. McWilliams, J. Dockall, and M. C. Wilder

2006 National Register Testing of Seven Prehistoric Sites in the Sabine Mine's Area Q, Harrison County, Texas. Reports of Investigations No. 147. Prewitt and Associates, Inc., Austin.

Hart, J. P.

1982 An Analysis of the Aboriginal Ceramics from the Washington Square Mound Site, Nacogdoches County, Texas. Master's thesis, Department of Anthropology, Northeast Louisiana University, Monroe.

Jones, B. C.

1957 The Grace Creek Sites, Gregg County, Texas. Bulletin of the Texas Archeological Society 28:198-231.

1968 The Kinsloe Focus: A Study of Seven Historic Caddoan Sites in Northeast Texas. Master's thesis, Department of Anthropology, University of Oklahoma, Norman.

Perttula, T. K.

1995 Collected Papers on Caddoan Archaeology in the Upper Sabine River Basin, Northeastern Texas. Special Publication No. 1. Friends of Northeast Texas Archaeology, Pittsburg and Austin.

2011 Another Look at the Grace Creek \#I Site in Gregg County, Texas, as Seen Through Ceramic Analysis. Journal of Northeast Texas Archaeology 35:11-46.

2012 Three Mounds Creek Site, Gregg County, Texas. Journal of Northeast Texas Archaeology 36:33-36.

2013 Additional Ancestral Caddo Ceramic and Lithic Artifacts from the Three Mounds Creek Site, Gregg County, Texas. Journal of Northeast Texas Archaeology 40:61-63.

Perttula, T. K. and B. Nelson

2013 Two Middle Caddo Period Habitation Sites and Cemeteries in the Sabine River Basin, Gregg County, Texas. Special Publication No. 27. Friends of Northeast Texas Archaeology, Pittsburg and Austin.

Perttula, T. K., B. Nelson, and M. Walters

2012 Caddo Archaeology at the Henry Spencer Site (4IUR315) in the Little Cypress Creek Basin of East Texas. Special Publication No. 20. Friends of Northeast Texas Archaeology, Pittsburg and Austin.

Perttula, T. K., M. Walters, B. Nelson, B. Gonzalez, and R. Cast, with a contribution by R. G. Franciscus 2010 Documentation of Associated and Unassociated Caddo Funerary Objects in the Stephen F. Austin State University Collections, Nacogdoches, Texas. Stephen F. Austin State University Press, Nacogdoches.

Suhm, D. A. and E. B. Jelks (editors)

1962 Handbook of Texas Archeology: Type Descriptions. Special Publication No. 1, Texas Archeological Society, and Bulletin No. 4, Texas Memorial Museum, Austin.

Walters, M., with contributions from L. G. Cecil. L. S. Cummings, J. P. Dering, J. R. Ferguson, M. D. Glascock,

T. K. Perttula, L. Schniebs, H. J. Shafer, J. Todd, and C. P. Walker

2008 Life on Jackson Creek, Smith County. Texas: Archeological Investigations of a $14^{\text {th }}$ Century Caddo Domicile at the Leaning Rock Site (41SM325). Caddo Archeology' Journal 17:1-114.

Walters, M., with contributions by T. Middlcbrook and T. K. Perttula

2010 Redwine or Pie-Crust Mode Forms in East Texas Caddo Ceramics and comparisons with Sprocket-Rims of Southwest Arkansas. Caddo Archeology Journal 20:77-128. 